\title{
THE EFFECT OF SEXUAL DUE TO THE PRODUCTION OF SEMEN ON ONGOLE CROSSBRED
}

\author{
Sholikah Nisa'us*, Patguri Mayova, Yekti Aulia Puspita Anugra, Kuswati, \\ Wahjuningsih Sri, Susilawati Trinil \\ Faculty of Animal Husbandry, University of Brawijaya, Indonesia \\ *E-mail: nisaus.sholikah@gmail.com
}

\begin{abstract}
Ongole crossbred (CO) is a local cow that has long been bred in Indonesia. One strategy to increase population is to produce frozen semen with good quality. Semen production is influenced by libido which is known through male sexual behavior. The purpose of this study was to determine the effect of sexual behavior on semen production. The research material included 3 OC cattle studs aged 4-5 years with a body weight of $500-600 \mathrm{~kg}$. Semen is collected twice a week using the artificial vaginal method. The method used in the study was observational. Sexual behavior parameters include libido and ejaculation duration. Semen production variables are known by calculating total spermatozoa and total motile spermatozoa. Data were analyzed using Randomized Block Design (RBD) consisting of 3 treatments and 10 replications. If there is a difference, continue with Duncan's Multiple Distance Test. The relationship between sexual behavior and semen production was calculated by Pearson correlation and its effect was calculated by linear regression. The results showed that the length of libido was not significant $(P>0.05)$, the duration of ejaculation was significantly $(P<0.01)$, the total spermatozoa was significantly $(P<0.01)$, and the total motile spermatozoa was significantly $(P<0.01)$ in all three male males. The relationship between the duration of libido and semen production was insignificant $(P>0.05)$, while the duration of ejaculation had a significant relationship $(P<0.05)$ to total spermatozoa with R2 $=22.15 \%$ and total motile spermatozoa with R2 $=25.84 \%$. The conclusion of the study was that there was an influence on sexual behavior on semen production in OC cattle.
\end{abstract}

\section{KEY WORDS}

Ongole crossbred, libido, sexual behavior, semen production

Ongole crossbred $(\mathrm{OC})$ cattle are local cows produced by crosses that are cultivated for quite a long time in Indonesia. In 1991 the OC cattle population reached 4.6 million head and in 2001 the population dropped by 874,000 by concentration on Java (Astuti, 2004). The increased population of $O C$ cattle used to increase the potential of existing local cattle. One way to increase $O C$ cattle population is to produce frozen semen with very precise and reproductive requirements and have a good appearance (Susilawati, 2017c).

The Center for Artificial Insemination (BBIB) located in Singosari, Malang, East Java is a hall that provides frozen semen and has several local or exotic cattle countries. The process of selecting superior males is done by holding semen and testing the quality of spermatozoa to semen to determine the fertility level.

The quality and production of semen by genetic and environmental factors. Genetic factors include libido, nation, scrotal circumference, and age. Environmental factors include feed, temperature, and shelter (Susilawati et al., 2017). Spermatozoa with good quality and quantity can be obtained by male regulation, adequate feed, male health, and generation of sexual behavior before copulation.

Sexual behavior can refer to livestock libido which influences semen production and quality (Arman, 2014 and Herwijanti, 2004). The more often we do the behavior, the production of spermatozoa increases but the volume per ejaculation decreases. Sexual behavior includes the duration of libido, false installation, thrust, pinching, long ejaculation and erectile quality (Herwijanti, 2004). Ismaya (2014) explains libido also by heredity or genetics. Sexual behavior needs to be considered to bring up relevant signs of behavior in 
predicting activities so that they can be visited early (Solano et al., 2005). The aim of this study was to publish the results of spermatozoa production in PO cow males used for frozen semen production.

\section{MATERIALS AND METHODS OF RESEARCH}

The research material used included OC cattle with an age of 4-5 years as many as 3 with a body weight of $500-600 \mathrm{~kg}$. Semen is collected twice a week using the artificial vaginal method. Tools and materials used in semen storage and semen production observations are as follows:

- Semen shelter. Tools include artificial vagina, storage tube, protector jacket, corn, black cloth cover, thermometer and clamp enclosure with materials used include anglers, ky jelly, warm water and tissue.

- Observation of semen production. Tools include microscope, osse, glass cover, glass object, socorex pipette, litmus paper, spectrophotometer and cool top with materials used including semen

The method used in this study was observational with 3 treatments and 10 replications. The research treatment was individual 1 (Bromo), individual 2 (Alindo) and individual 3 (Akbar) with 10 replications namely semen storage. Variables observed in sexual behavior include libido duration and ejaculation duration according to Herwijanti (2004). The duration of libido is the first time the male rises to the teaser, calculated from the male close to the teaser until the first false mounting, the calculation using a stopwatch. The duration of ejaculation is calculated from the time the male is brought close to the teaser until the ejaculation occurs in the artificial vagina, the calculation using a stopwatch.

Variables observed for semen quality including volume, concentration, and motility of spermatozoa individuals were observed to semen production, namely total spermatozoa and total motile spermatozoa per ejaculate according to Ax et al (2008) and Susilawati (2013), namely:

- $\quad$ total spermatozoa $=$ volume $x$ concentration;

- $\quad$ total motile spermatozoa = volume $x$ concentration $x$ individual motility .

The data obtained were analyzed using statistical analysis of Randomized Block Design (RBD) to determine differences between individuals. If there is a difference followed by Duncan's Multiple Distance Test (UJBD). Duration of ejaculation and duration of libido were correlated with total spermatozoa and total motile spermatozoa.

Table 1 - Correlation Coefficient Value

\begin{tabular}{cc}
\hline R Value & Interpretation \\
\hline $0,00-0,199$ & Correlation is very weak \\
$0,20-0,399$ & Weak correlation \\
$0,40-0,599$ & Medium correlation \\
$0,60-0,799$ & Strong correlation \\
$0,80-1,000$ & Correlation is very strong \\
\hline
\end{tabular}

Source: Sugiyono, 2007.

\section{RESULTS AND DISCUSSION}

Sexual behavior reflects the ability of males to initiate sexual activity that gives an idea of the reproductive performance of a livestock so that it can be used as a seed for Artificial Insemination purposes (Salim, 2017).

Long libido. Libido is the desire of males to mate. The duration of libido can be measured by calculating the time when the male is brought close to the angler until the first false mounting. The results of the variance analysis showed that each individual did not give a significant difference $(P>0.05)$ to the duration of libido. 
Table 2 - Average libido duration of Ongole crossbred

\begin{tabular}{cc}
\hline Individual & Long libido (minute) \pm SD \\
\hline Bromo & $0,61 \pm 0,89$ \\
Alindo & $0,68 \pm 0,83$ \\
Akbar & $0,21 \pm 0,24$ \\
\hline
\end{tabular}

The mean value lies in $(0.21 \pm 0.24)$ to $(0.68 \pm 0.83)$. The highest duration of libido is in the individual Alindo and the lowest in the individual Akbar. Good libido is indicated by the rapid response when brought near to the angler. The duration of libido under 60 seconds is categorized as good (Herwijanti, 2004). The three individuals still have libido that is not much different.

Based on the results of field observations the shelter process carried out on the three OC cattle has the same angler and location according to the preferences of each individual. The atmosphere in the shelter is made calm so that individuals are not disturbed by the surrounding environment. This can be applied with the collector's position on the individual side and not standing in front of the individual because it can disturb the concentration and direct the restraint rope towards the back of the angler to focus the livestock. This is in accordance with Sumeidiana et al (2007) that creating a calm atmosphere around shelters, feed factors, and conditions for the same shelter can be done to increase libido.

Long Ejaculation. Ejaculation is the release of semen from the penis during the peak of libido. The duration of ejaculation is the time when the male is brought near the angler until the ejaculation occurs. The results of the variance analysis showed that each individual gave a significantly difference $(P<0.01)$ for the duration of ejaculation.

Table 3 - Average Ejaculation Length of Ongole Crossbred

\begin{tabular}{cc}
\hline Individual & Long Ejaculation (minute) \pm SD \\
\hline Bromo & $3,80 \pm 1,51^{\mathrm{a}}$ \\
Alindo & $3,07 \pm 0,99^{\mathrm{a}}$ \\
Akbar & $7,28 \pm 4,15^{\mathrm{b}}$ \\
\hline
\end{tabular}

The mean value lies in $(3.07 \pm 0.99)$ to $(7.28 \pm 4.15)$. The highest duration of ejaculation lies in the Akbar individual and the lowest among Alindo individuals. Table 3 shows that Akbar individuals have ejaculation duration of 7.28 minutes. This value is different from the other three individuals, because when the conditions in the field occur collector turnover and angling in Akbar's individual causes the level of preference for habits decreases along with the expertise of officers at the shelter which affects whether or not the male is to be accommodated.

This agrees with Susilawati (2013b) that the nation, age, scrotal circumference, adaptability, and environmental situation when accommodated and the expertise of officers influence the quality and quantity of semen produced.

The process of ejaculation according to (Waluyo, 2014) spermatogenesis that occurs in the seminiferous tubules will be channeled by cilia which move the spermatozoa to the retetestes, vas defferens epididymis, vas efferens and finally in the urethra; the process of transportation when flowing into the vas deferens, contraction of the seminal vesical smooth muscle and prostate secreting seminal plasma (Ax et al., 2008) so that the spermatozoa with the seminal plasma form semen out through the ejaculatory duct and urethra then emitted through the penis.

Total Spermatozoa. The results of the variance analysis showed that each individual gave a significantly $(P<0.01)$ to total spermatozoa.

Table 4 - Average Total Spermatozoa of Ongole crossbred

\begin{tabular}{cc}
\hline Individual & TS (Million) \pm SD \\
\hline Bromo & $7.892,28 \pm 2.476,04^{\mathrm{a}}$ \\
Alindo & $6.729,93 \pm 2.305,49^{\mathrm{a}}$ \\
Akbar & $10.787,38 \pm 2.542,86^{\mathrm{b}}$ \\
\hline
\end{tabular}


The mean value is located at $(6,729.93 \pm 2,305.49)$ to $(10,787.38 \pm 2,542.86)$. The highest total spermatozoa lies in the Akbar individual and the lowest in Alindo individuals. Field results showed total spermatozoa in all three individuals categorized accordingly according to Garner and Hafez (2008) who argued that semen concentrations varied from 1,000-1,800 million spermatozoa per milliliter.

Total Spermatozoa Motil. The results of the variance analysis showed that each individual gave a significantly difference $(P<0.01)$ to the total motile spermatozoa.

Table 5 - Average Total Spermatozoa Motil of Ongole crossbred

\begin{tabular}{cc}
\hline Individual & TSM (Million) \pm SD \\
\hline Bromo & $5.145,19 \pm 1.765,76^{\mathrm{a}}$ \\
Alindo & $4.893,48 \pm 1.645,06^{\mathrm{a}}$ \\
Akbar & $7.182,72 \pm 1.843,39^{\mathrm{b}}$ \\
\hline
\end{tabular}

The mean value lies in $(4,893.48 \pm 1,645.06)$ to $(7,182.72 \pm 1,843.39)$. The highest total motile spermatozoa lies in the large individual and the lowest in Alindo individuals. The results showed that the three individuals had total spermatozoa above the average in the study. Sholikah et al (2016) argue that total progressive spermatozoa per ejaculate will determine success in fertilization. Ax et al (2008) and Susilawati (2011a) argue that the older cows will result in improved quality but after 7 years it will decline. In puberty animals, abnormal spermatozoa are found. In young animals the volume of semen is less. It also affected the total motile spermatozoa in Akbar individual semen which had a different age from other individuals, namely 5 years with the highest total spermatozoa.

Relationship between Old libido and Spermatozoa Production. Based on the regression relationship obtained a value that is not real $(P>0.05)$ with a positive correlation coefficient (r) of 0.04 . The correlation shown proves the degree of closeness between the two very low variables between the duration of libido and the total spermatozoa.

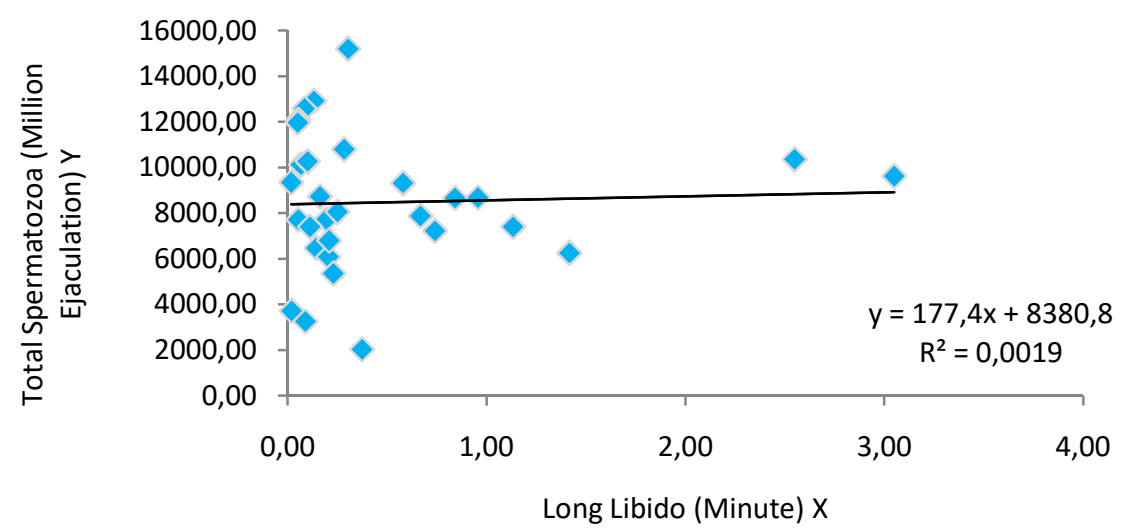

Figure 1 - Relationship between libido duration and total spermatozoa in OC cattle

The effect of the duration of libido on total spermatozoa is illustrated by the coefficient of determination R2 of $0.001 \%$, meaning that the length of libido affects the total spermatozoa by $0.001 \%$ and the rest is influenced by other factors. The third individual regression equation is $y=177.4 x+8,380.8$ which means that if the length of libido increases every unit, it will increase the total number of spermatozoa by 177.4. Sumeidiana et al (2007) argue that high libido will produce high accessory glands and high plasma seminal production, which will squeeze the spermatozoa stored in the epididymis during ejaculation which causes high production of spermatozoa produced.

Relationship between Long libido and Spermatozoa Motil Production. Based on the regression relationship, the values that were insignificant $(P>0.05)$ between the length of libido and total motile spermatozoa with a positive correlation coefficient $(r)$ of 0.08 . The correlation shown proves the degree of closeness between the two very low variables between the duration of libido and the total spermatozoa. 


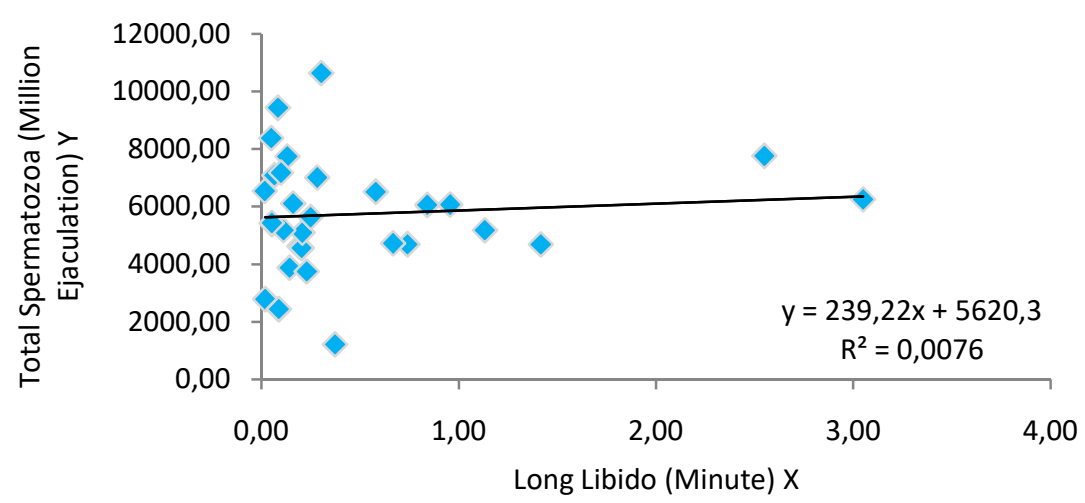

Figure 2 - Relationship between libido duration and total Spermatozoa Motil OC cattle

The effect of the duration of libido on total spermatozoa is illustrated by the coefficient of determination R2 of $0.007 \%$ meaning that the length of libido affects the total spermatozoa by $0.007 \%$ and the rest is influenced by other factors. The third individual regression equation is $y=239.22 x+5,620.3$ which means that if the length of libido increases every unit, it will increase the total number of motile spermatozoa by 239.22. Brito et al (2002) stated that total motile spermatozoa was influenced by age. In all three individuals having different ages, Akbar's individuals have 5 years of age and the other two individuals have 4 years of age.

Relationship between Ejaculation and Spermatozoa Production. Based on the regression relationship obtained value $(P<0.05)$ between the duration of ejaculation and total spermatozoa with a positive correlation coefficient $(r)$ of 0.47 . The correlation shown proves a moderate correlation between the duration of ejaculation and total spermatozoa.

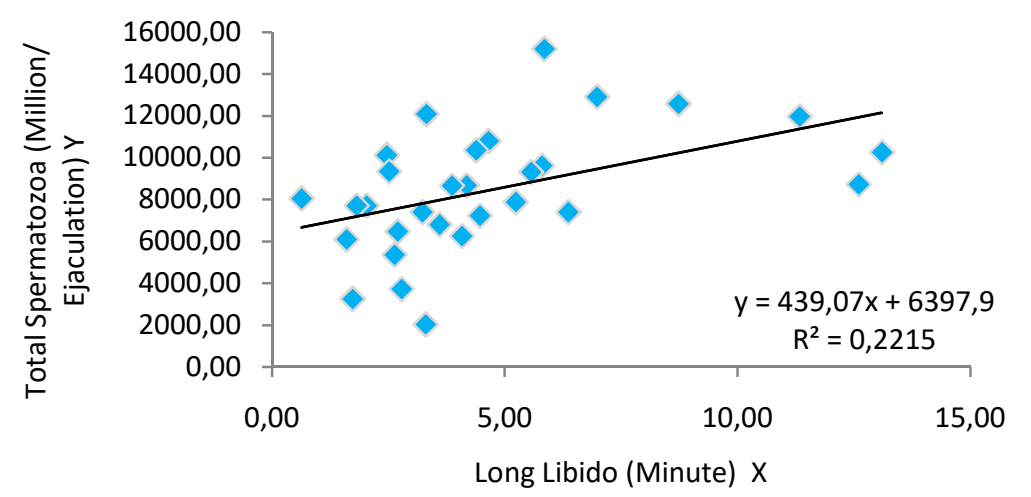

Figure 3 - Relationship between Ejaculation and Total Spermatozoa

The effect of ejaculation duration on total spermatozoa is illustrated by the coefficient of determination R2 of $0.2215 \%$ meaning that the length of libido affects the total spermatozoa by $22.15 \%$ and the rest is influenced by other factors. The third individual regression equation is $y=439.07 x+6,397.9$ which means that if the duration of ejaculation increases every unit, it will increase the total number of spermatozoa by 439.07. Prolonged ejaculation distance, causing the semen results in many abnormal spermatozoa because they are piled up in the epididymis and vas deferens (Susilawati et al., 2017).

Relationship between Ejaculation Duration and Spermatozoa Motil Production. Based on the regression relationship obtained a value $(P<0.05)$ between the duration of ejaculation and total motile spermatozoa with a positive correlation coefficient $(r)$ of 0.50 . The correlation shown proves a moderate correlation between the duration of ejaculation and total motile spermatozoa. 


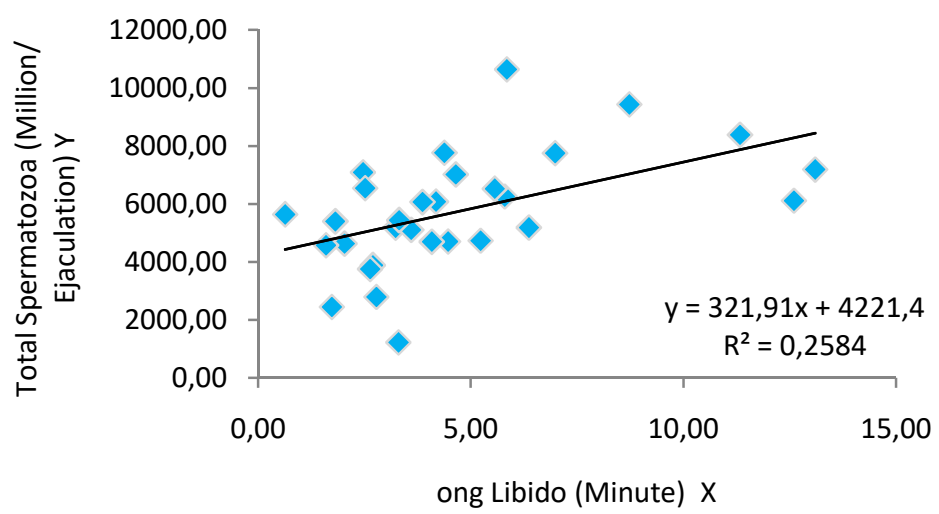

Figure 4 - Relationship between Ejaculation Duration and Total Spermatozoa Motil

The effect of ejaculation duration on total motile spermatozoa is described by the coefficient of determination $\mathrm{R}^{2}$ of $0.2584 \%$, meaning that the length of libido affects the total spermatozoa by $25.84 \%$ and the rest is influenced by other factors. The third individual regression equation is $y=321.91 x+4,221.4$ which means that if the duration of ejaculation increases every unit, it will increase the total number of motile spermatozoa by 321.91 . Komariah et al. (2013) argue that many factors influence the difference in motility values of spermatozoa including age, nation, maturity of spermatozoa, and the quality of plasma spermatozoa.

\section{CONCLUSION}

Based on the results of research and discussion, it can be concluded that:

- The duration of libido and duration of ejaculation in OC cattle has a positive correlation with total spermatozoa and total motile spermatozoa. The higher the duration of libido and the longer the ejaculation, the more total spermatozoa and total motile spermatozoa.

- The average length of libido in OC cattle is 0.48 minutes; duration of ejaculation 4.11 minutes; total spermatozoa 7,755.8 million / ejaculate; total motile spermatozoa $5,271.33$ million/ejaculate.

\section{ACKNOWLEDGMENTS}

Thank you to the Education Fund Management Institute (LPDP) of the Ministry of Finance of the Republic of Indonesia for funding research and the Singosari Malang Institute for Artificial Insemination which provides a place of research.

\section{REFERENCES}

1. Arman, C. 2014. Reproduksi Ternak. Graha ilmu. Yogyakarta.

2. Astuti, M. 2004. Potensi dan Keragaman Sumberdaya Genetik Sapi Peranakan Ongole (PO). Jurnal Wartazoa. 14(3) : 98-106.

3. Ax, R. M., Dally., B. Didion., R. Lenz., C. Love., D. Vaner., Hafez and M. Bellin. 2008. Semen evaluation in reproduction in farm animal. $7^{\text {th }}$ Edition Edited by Hafez, E.S.E. Co Director. Reproducive Health Kiawah Island. South Carolina. United States of America: 365-370.

4. Brito, L.F.C., A. E. D. F. Silva., L. H. Rodriques., F. V. Vieira., L. A. G Deragon and J. P. Kastelic. 2002. Effects of environmental Factors, Age and Genotype on Sperm Production and Quality in Bos indicus and Bos taurus ARTICIFIAL INSEMINATION bulls in Brazil. Animal Reproduction Seience. 70: 181-190. 
5. Garner, D.L and E.S.E. Hafez. 2008. Spermatozoa and Plasma Semen In Reproduction in Farm Animal. Hafez, E.S.E. and B. Hafez (eds). 7th ed. Lippincott \& Williams. Baltimore, Marryland, USA: 82-95.

6. Herwijanti, E. 2004. Pengaruh Tingkah Laku Seksual Terhadap Kualitas Semen Pada BerbagArticifial Insemination Bangsa Sapi Potong. Tesis. Malang : Universitas Brawijaya.

7. Ismaya. 2014. Bioteknologi Inseminasi Buatan pada Sapi dan Kerbau. Universitas Gadjah Mada Press (UGM Press). Yogyakarta.

8. Komariah, L., Arifiantini dan F.W. Nugraha. 2013. Kaji Banding Kualitas Spermatozoa Sapi Simmental, Limousin, dan Friesian Holstein Terhadap Spermatozoa Kambing Boer Setelah Penyimpanan Dingin. Buletin Peternakan. 37(3) : 143-147.

9. Salim, M. A. 2017. Evaluasi Tingkah Laku Sexual Kambing Kacang Jantan di Unit Pemukiman Transmigrasi (UPT) Desa Bina Gara Kabupaten Halmahera Timur. Jurnal Agripet. 17(1): 7-14.

10. Sholikah, N., N. IsnArticifial Inseminationni., A.P.A. Yekti dan T. Susilawati. 2016. Pengaruh Penggantian Bovine Serum Albumin (BSA) dengan Putih Telur pada Pengencer CEP-2 terhadap Kualitas Semen Sapi Peranakan Ongole pada Suhu Penyimpanan $3-5^{\circ} \mathrm{C}$. Jurnal IImu-IImu Peternakan. 26(1): 7-15.

11. Solano, J., A. Orihuela., C.S. Galina., F. Montiel and F. Galindo. 2005. Relationship between social behaviour and mounting activity of Zebu Cattle (Bos indicus). Journal Applied Animal Behaviour Science 94:197-203

12. Sumeidiana, I., S. Wuwuh dan E. Mawarti. 2007. Volume Semen dan Konsentrasi Sperma Sapi Simmental, Limousin dan Brahman di BalArticifial Insemination Inseminasi Buatan Ungaran. Jurnal Indon.Trop.Anim.Agric Semarang. 32 : 2.

13. Susilawati, T. $2011^{\mathrm{a}}$. Spermatology. Universitas Brawijaya. (UB) Press. Malang.

14. Susilawati, T. 2013 . Pedoman Inseminasi Buatan Pada Ternak. Universitas Brawijaya. UB Press. Malang.

15. Susilawati, T. $2017^{c}$. Sapi Lokal Indonesia (Jawa Timur dan Bali). Universitas Brawijaya. UB Press. Malang.

16. Susilawati, T., A.P.A. Yekti., M.N. Ihsan dan S. Wahyuningsih. 2017. Fisiologi Reproduksi Ternak. UB Press. Malang.

17. Waluyo, S.R. 2014. Reproduksi Aplikatif pada Sapi. Srikandi Empat Widya Utama. Bandung. 